\title{
ERK8 is a novel HuR kinase that regulates tumour suppressor PDCD4 through a miR-21 dependent mechanism
}

\author{
Urszula Liwak-Muir ${ }^{1}$, Christine C. Dobson ${ }^{1}$, Thet Naing ${ }^{1}$, Quinlan Wylie ${ }^{1}$, Lucia \\ Chehade $^{1}$, Stephen D. Baird ${ }^{1}$, Pranesh K. Chakraborty ${ }^{2,3}$ and Martin Holcik ${ }^{1,2}$ \\ ${ }^{1}$ Molecular Biomedicine Program, Children's Hospital of Eastern Ontario Research Institute, Ottawa, ON, Canada \\ 2 Department of Pediatrics, University of Ottawa, Ottawa, ON, Canada \\ ${ }^{3}$ Newborn Screening Ontario, Children's Hospital of Eastern Ontario, University of Ottawa, Ottawa, ON, Canada \\ Correspondence to: Martin Holcik, email: martin@arc.cheo.ca
}

Keywords: tumour supressor, miRNA, kinase

Received: September 14, $2015 \quad$ Accepted: November 16, 2015

Published: November 22, 2015

\begin{abstract}
Programmed cell death 4 (PDCD4) is a tumour suppressor implicated in cancer development and progression and was recently identified as a repressor of capindependent translation of specific genes involved in the regulation of apoptosis. We show that the RNA-binding protein HuR binds to the PDCD4 3'UTR to protect it from miR-21-induced silencing. However, following $\mathrm{H}_{2} \mathrm{O}_{2}$ treatment, PDCD4 mRNA is degraded via miR-21 binding. Importantly, we identify HuR as a novel substrate of the ERK8 kinase pathway in response to $\mathrm{H}_{2} \mathrm{O}_{2}$ treatment. We show that phosphorylation of HuR by ERK8 prevents it from binding to PDCD4 mRNA and allows miR-21-mediated degradation of PDCD4.
\end{abstract}

\section{INTRODUCTION}

RNA binding proteins (RBPs) have many important roles in the post-transcriptional control of RNAs including splicing, stabilization, translation and localization of multiple mRNA targets. Normally located in the nucleus, RBPs can accumulate in the cytoplasm in response to cellular stress to regulate specific mRNA targets, allowing the cell to recover from stress or to undergo apoptosis. $\mathrm{HuR}$ is a ubiquitously expressed RBP belonging to the $\mathrm{Hu} / \mathrm{embryonic}$ lethal abnormal vision (ELAV) protein family [1]. HuR localizes primarily to the nucleus where it is involved in regulating mRNA splicing [2], export [3], and polyadenylation [4] via its three RNA recognition motifs (RRMs). Notably, a hinge region between RRM2 and RRM3 contains a nucleocytoplasmic shuttling domain that shuttles HuR into the cytoplasm in response to cellular stressors such as UV, arsenite, and hydrogen peroxide $\left(\mathrm{H}_{2} \mathrm{O}_{2}\right)[5,6]$. The cytoplasmic accumulation of HuR allows it to modulate mRNA stability and translation [7-9]. HuR mainly functions by binding to AU-rich elements (AREs) in the 3' untranslated regions (UTRs) of target mRNAs. However, HuR can also bind the 5'UTR, where it has been shown to either positively or negatively regulate translation. For example, HuR binds to the 5'UTR of IGF-IR and Bcl-xL to repress their translation $[9,10]$. In contrast, binding of HuR enhances the IRES-mediated translation of XIAP [8]. In addition, HuR has been implicated in translational regulation through its ability to impact microRNAs, although the precise mechanism is not clear. In a competitive role, the binding of HuR to the mRNA may prevent miR/RISC (RNA-induced silencing complex) binding, thus resulting in stabilization of the target mRNA and an increase in translation [11]. Conversely, HuR binding may result in conformational changes in the mRNA that promote miR/RISC binding, leading to mRNA degradation or translation inhibition [11]. Given the diverse functions of HuR, it is no surprise that it plays a major role in the initiation and progression of cancer. This occurs mainly through its ability to regulate the stability or translation of target mRNAs involved in tumour growth, angiogenesis, invasion, and metastasis [12].

Programmed cell death 4 (PDCD4) is a tumour suppressor protein whose expression is increased during apoptosis [13], and has been implicated in the 
development of lung, colon, liver, breast, and brain cancers [14-18]. PDCD4 binds to and inhibits the eukaryotic initiation factor (eIF) 4A, the main helicase required for cap-dependent translation, suggesting a role as a general inhibitor of translation $[19,20]$. In addition, PDCD4 was shown to inhibit the translation of several specific mRNA targets such as p53 [21], XIAP and Bcl-xL [22] through a cap-independent mechanism. We recently demonstrated that the loss of PDCD4 in Glioblastoma multiforme (GBM) tumours correlates with an increase in Bcl-xL expression, and that re-expression of PDCD4 results in down-regulated $\mathrm{Bcl}-\mathrm{xL}$ expression and increased sensitivity to chemotherapeutics [18]. Determining the mechanism of PDCD4 regulation is crucial to better understand tumorigenesis. At the protein level, PDCD4 can be phosphorylated by $\mathrm{S} 6$ kinase 1 (S6K1) in response to mitogens [23] or S6K2 in response to fibroblast growth factor -2 (FGF-2) [22, 24], leading to its degradation. PDCD4 is also regulated at the mRNA level by microRNA (miR)-21, which is overexpressed in a variety of cancers [25-27].

Here, we describe a novel observation where HuR controls PDCD4 expression by regulating miR-21 binding to PDCD4 mRNA. We show that reducing HuR levels by siRNA results in a loss of PDCD4 that is mediated through miR-21. We further demonstrate that treatment of cells with $\mathrm{H}_{2} \mathrm{O}_{2}$ leads to the loss of PDCD4 that is executed through miR-21. We show that treatment of cells with $\mathrm{H}_{2} \mathrm{O}_{2}$ results in activation of Extracellular Signal Regulated Kinase 8 (ERK8, Mitogen-Activated Protein Kinase 15, MAPK15) and subsequent phosphorylation of HuR by ERK-8. Once phosphorylated, HuR loses its ability to bind the PDCD4 mRNA, thus making it available for miR-21-mediated repression.

\section{RESULTS}

\section{HuR controls PDCD4 protein expression by regulating $\mathrm{mRNA}$ stability}

To better understand the role of HuR in regulating PDCD4, we transiently transfected HeLa cells with small interfering (si) RNA against HuR and observed a marked reduction in PDCD4 protein levels (Figure 1A). Since HuR is known to bind to AU-rich elements (ARE) in the 3'UTR regions of many mRNAs, and the 3' UTR of PDCD4 is AU-rich (http://utrdb.ba.itb.cnr.it/) we measured the steady-state mRNA levels of PDCD4 after HuR knockdown. Indeed, we observed a 50\% decrease in PDCD4 mRNA (Figure 1B) as compared to control. Additionally, we performed Actinomycin D experiments after HuR knockdown and calculated the half-life of PDCD4 mRNA as $11.6 \mathrm{~h}$ in control cells and $9.5 \mathrm{~h}$ after HuR knockdown (Figure 1C) which suggests that a loss of HuR results in the loss of PDCD4 mRNA stability. In order to identify if PDCD4 is a target mRNA that HuR specifically binds to, we immunoprecipitated endogenous HuR from HeLa cells and analyzed bound RNAs by qRTPCR. We were able to successfully immunoprecipitate HuR (Figure 1D top panel) and isolation of bound RNAs followed by qRT-PCR identified that PDCD4 mRNA is enriched in HuR IP as compared to IgG control (Figure 1D bottom panel). It is possible that this observed interaction is indirect; therefore, we performed in vitro binding experiments with purified recombinant GST-tagged HuR and in vitro transcribed ${ }^{32} \mathrm{P}$-labelled PDCD4 3'UTR to determine if $\mathrm{HuR}$ can directly bind to the PDCD4 UTR and observed dose-dependent binding of HuR to the PDCD4 3'UTR (Figure 1E). These observations demonstrate that HuR regulates PDCD4 mRNA stability by directly binding to its 3'UTR.

\section{HuR regulates PDCD4 mRNA stability via miR- 21}

Recently, HuR has been implicated in regulating some mRNAs through their miR binding sites [11]. Since PDCD4 is a known target of miR-21 [25], we investigated the potential of HuR to regulate PDCD4 through miR-21. First, we confirmed that PDCD4 is a target of miR-21 by transiently transfecting a miR21 mimic and observing a reduction in PDCD4 protein (Figure 2A) and mRNA (Figure 2B) levels. To determine if the effect of HuR knockdown on PDCD4 expression is mediated through miR-21, we overexpressed an antimiR-21 (that binds to endogenous miR-21) to inhibit its activity. HuR knockdown in combination with a nontargeting antimiR-control showed a decrease in PDCD4 expression. In contrast, this reduction was blocked when cells were treated with the antimiR-21 (Figure 2C). This data suggests that HuR prevents miR-21 from binding to the PDCD4 mRNA resulting in protection of the mRNA from degradation. One possible mechanism is that $\mathrm{HuR}$ binds directly to the miR site on the 3'UTR thus blocking the miR from binding directly $[11,28]$. To determine if HuR binds the miR-21 site on PDCD4 we generated three $200 \mathrm{nt}$ fragments from the first 610 nucleotides of the PDCD4 3'UTR (Figure 3A right panel). Fragment $\mathrm{S} 2$ contains the miR-21 site highlighted in grey. We performed UV cross-linking experiments with purified GST-tagged HuR (Figure 3A left panel) and ${ }^{32} \mathrm{P}$-labelled in vitro transcribed RNA probes. Interestingly, $\mathrm{HuR}$ did not bind to the miR-21 containing fragment S2 (Figure 3B). Instead, HuR bound specifically to the first $200 \mathrm{nt} \mathrm{S1}$ fragment. Moreover, HuR did not bind to the S3 fragment, which further supports the specificity of the HuR-PDCD4 mRNA interaction. Since HuR does not seem to interact with the miR-21 site, we were interested in determining if binding to the $\mathrm{S} 1$ fragment could cause multimerization of 


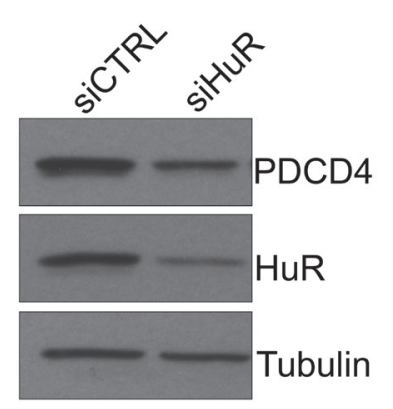

B

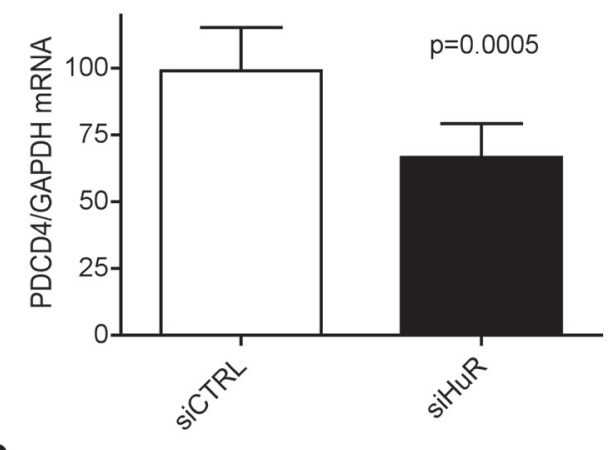

D
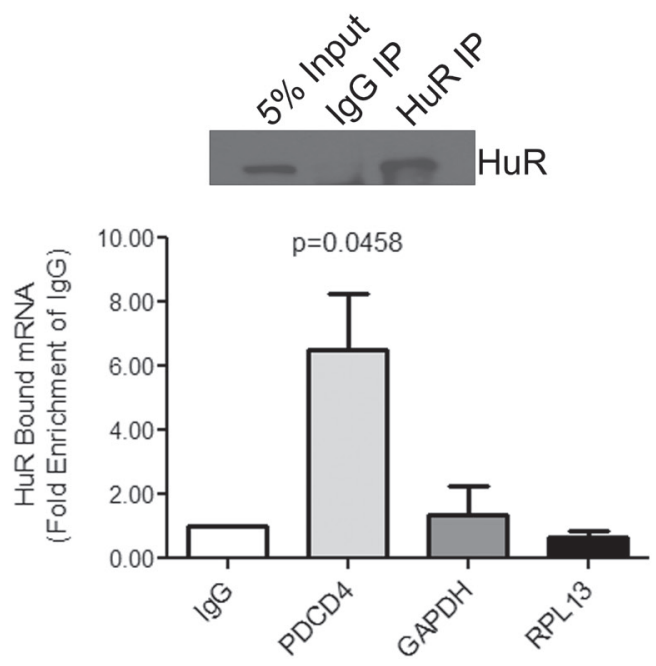

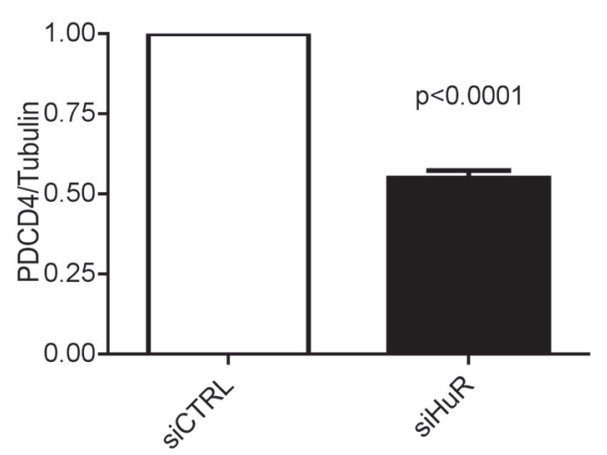

C

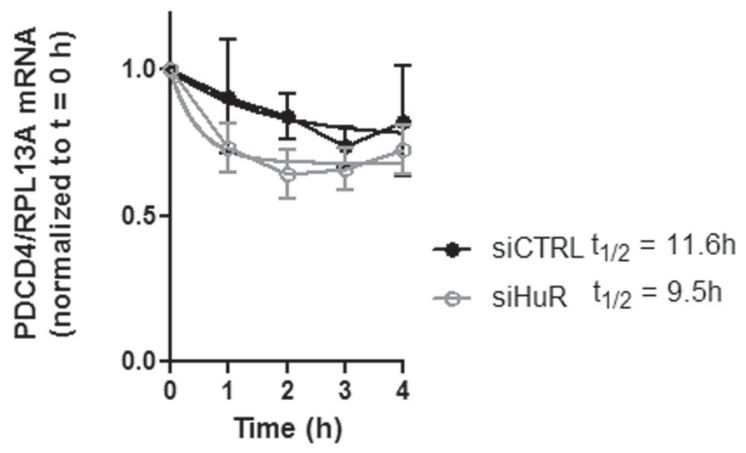

E

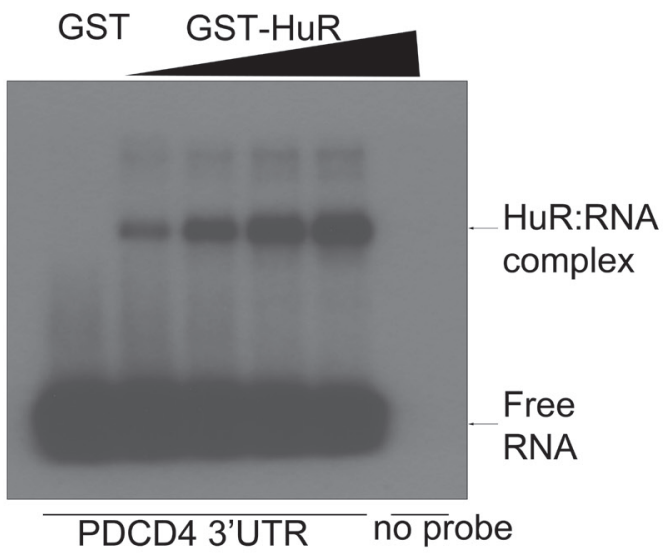

Figure 1: HuR directly binds to PDCD4 3'UTR mRNA to regulate its protein expression. A. Left panel: Western blot analysis of PDCD4 protein levels after HuR knockdown. HeLa cells were treated with siHuR or siCTRL (non-targeting control) for $72 \mathrm{~h}$ and harvested for western blot analysis. Tubulin was used as a loading control. Right panel: PDCD4 protein levels are quantified relative to Tubulin. B. HeLa cells were treated with siHuR or siCTRL for $72 \mathrm{~h}$, harvested, and total RNA was isolated. PDCD4 mRNA levels were quantified by qRT-PCR and are shown relative to GAPDH mRNA levels. C. Seventy-two hours after siRNA transfection, HeLa cells were treated with $5 \mu \mathrm{g} / \mathrm{mL}$ actinomycin D. After the chase period, cells were processed for qRT-PCR to determine the mRNA half-life (11.6h for siCTRL; 9.5h for siHuR). D. Top panel: HeLa cells were crosslinked with formaldehyde and endogenous HuR was immunoprecipitated with mouse anti-HuR antibody; $\operatorname{IgG}$ was used as a control. Western blot analysis shows the level of immunoprecipitated HuR. Bottom panel: HuR-bound RNA was isolated and quantified by qRT-PCR, and is shown relative to IgG-immunoprecipitated material. The levels of GAPDH and RPL13 in HuR immunoprecipitation were determined as specificity controls E. PDCD4 3'UTR RNA was in vitro transcribed, ${ }^{32} \mathrm{P}$ labelled and UV crosslinking was performed with recombinant GST (control) or GST-HuR, separated by SDS-PAGE, and exposed to X-Ray film. 
HuR on the mRNA to possibly inhibit the binding of the RISC complex. We performed RNA electromobility shift assays (EMSA) with increasing concentrations of purified GST-HuR and ${ }^{32} \mathrm{P}-$ labelled S1-S2 fragment (Nucleotides 1-400; Figure 3C). We observed the formation of four complexes with increasing concentrations of GST-HuR suggesting that HuR binds to the first $200 \mathrm{nt}$ of the PDCD4 3'UTR, and further multimerizes on the RNA. To further investigate the possible interplay between miR-21, HuR and PCDC4 mRNA, we used differentially labelled RNAs (Cy5.5-miR-21; ${ }^{32} \mathrm{P}-\mathrm{PDCD} 4$ 3' UTR) in an RNA-EMSA. Interestingly, although HuR binds miR21 (Figure 3D) as observed by the Cy5.5 signal (bottom), the presence of miR-21 does not impair HuR's ability to bind to and oligomerize on the PDCD4 RNA as observed by autoradiography (top). Although the binding of miR21 to PDCD4 3' UTR has been reported previously [25], we were unable to detect binding of miR-21 to PDCD4 RNA due to the low sensitivity of the Cy5.5 label (data not shown).

\section{Loss of PDCD4 expression after $\mathrm{H}_{2} \mathrm{O}_{2}$ treatment is mediated through miR-21 and ERK8}

Many cellular stresses, such as oxidative stress, result in an accumulation of cytoplasmic HuR that is usually mediated by phosphorylation of HuR [11]. This cytoplasmic accumulation is necessary for HuR's ability to stabilize mRNAs or control translation by placing HuR
A

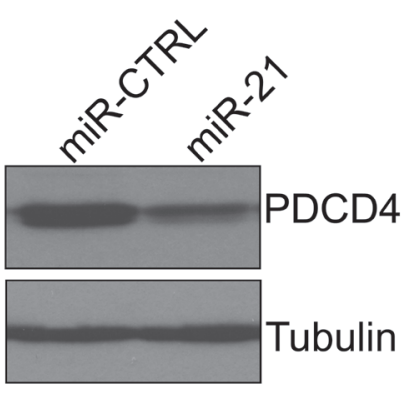

C

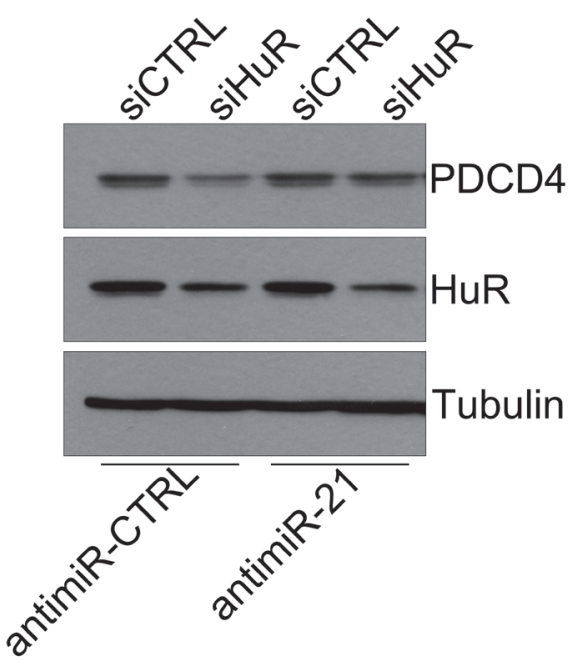

B
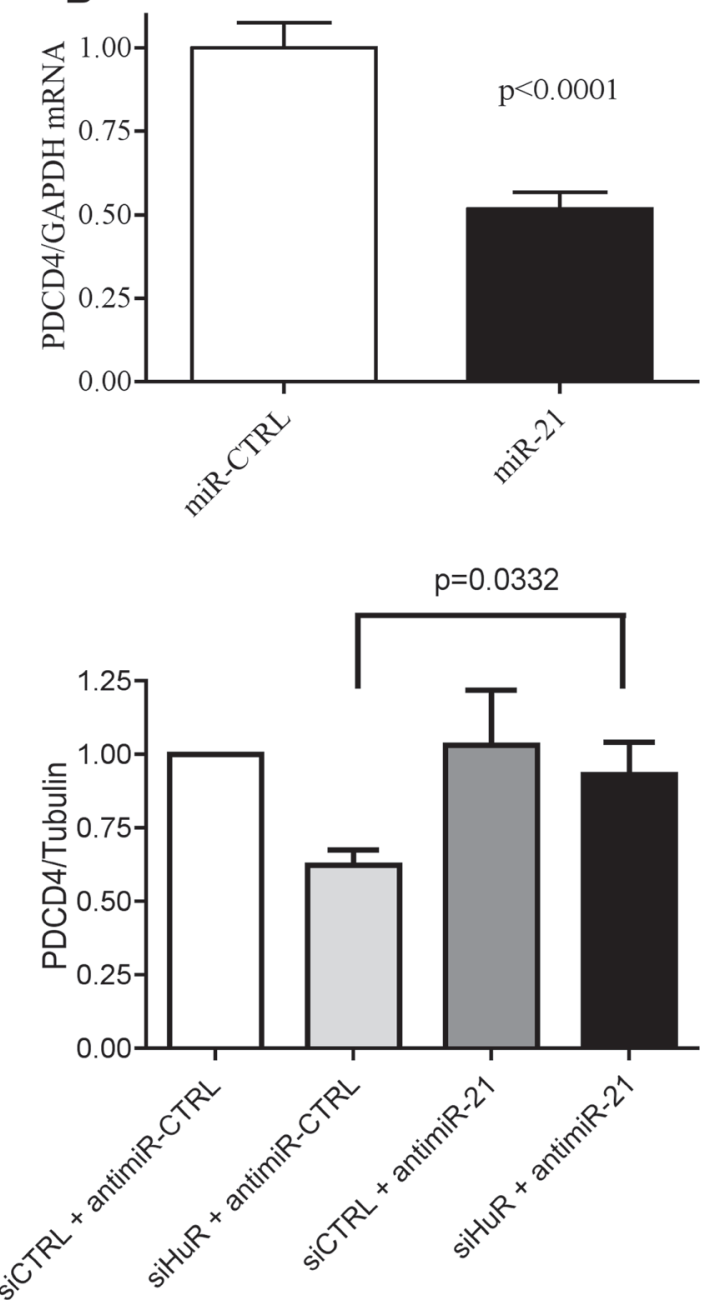

Figure 2: HuR regulates PDCD4 stability via miR-21. A. HeLa cells were transiently transfected with a miR-21 mimic for 24 $\mathrm{h}$ and cells were harvested for western blot analysis. Tubulin was used as a loading control. B. HeLa cells were transiently transfected with a miR-21 mimic for $24 \mathrm{~h}$ and RNA was harvested. qRT-PCR analysis showing decrease of PDCD4 mRNA relative to GAPDH after miR-21 over-expression. C. Left panel: AntimiR-21 or antimiR-CTRL (control) was transiently transfected into HeLa cells for $24 \mathrm{~h}$ followed by siHuR transfection for an additional $48 \mathrm{~h}$. Cells were harvested and protein levels were analyzed by western blot. Right panel: Quantification of PDCD4 protein levels relative to Tubulin. 
in the same sub-cellular compartment as its target mRNA. Therefore, we were interested in determining the effect of increased cytoplasmic HuR levels on PDCD4 expression. We were expecting that an increase in cytoplasmic HuR would provide a protective effect against miR-21dependent degradation, leading to increased PDCD4 expression. Contrary to our expectations, however, treatment of cells with $\mathrm{H}_{2} \mathrm{O}_{2}$ resulted in a loss in PDCD4 expression both at the protein (Figure 4B) and mRNA (Figure 4C) levels, even though HuR accumulated in the cytoplasm as monitored by immunofluorescence (Figure 4A). Additionally, we tested the requirement of miR-21 for PDCD4 loss during $\mathrm{H}_{2} \mathrm{O}_{2}$ treatment as it was shown previously that miR-21 levels increase following $\mathrm{H}_{2} \mathrm{O}_{2}$ treatment [29]. Cells were pretreated with antimiR-21 and then exposed to $\mathrm{H}_{2} \mathrm{O}_{2}$. Inhibition of miR-21 rescued
A

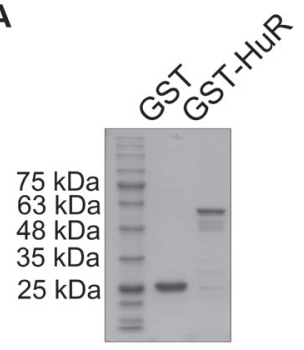

C

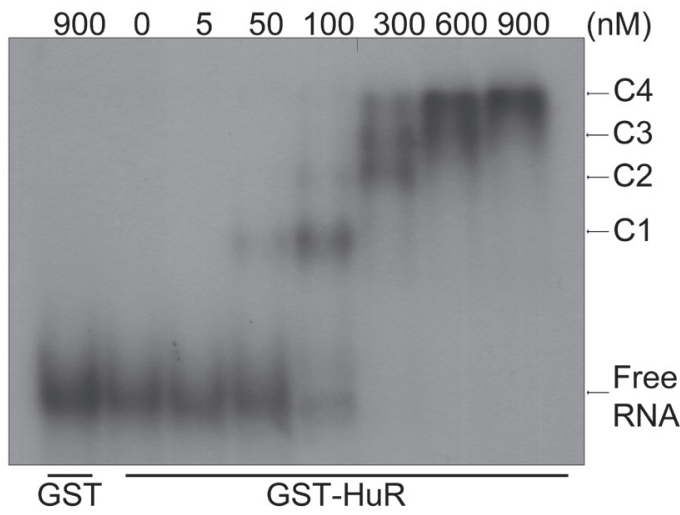

B

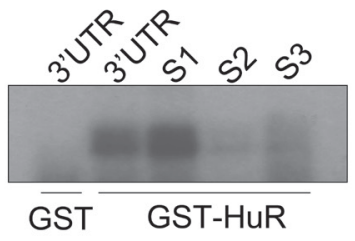

D

\begin{tabular}{cc|c|c|c|c|c|c|c|c|c|} 
PDCD4 & - & + & + & + & + & + & - & + & + & + \\
\hline & ++++ & - & + & ++ & +++ & ++++ & ++++ & - & ++ & ++++
\end{tabular}
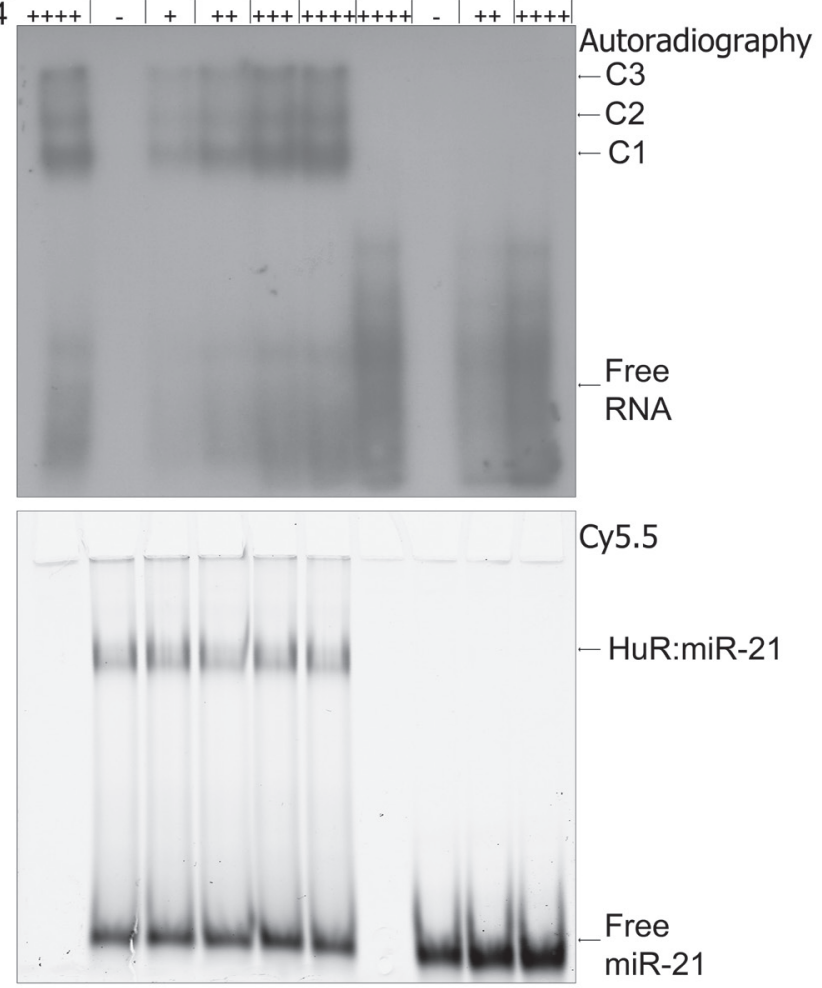

Figure 3: HuR oligomerizes on the PDCD4 3'UTR. A. Left panel: Coomassie stain of the recombinant GST and GST-HuR purified from E. coli cells. Right panel: Schematic representation of a fragment of the PDCD4 3'UTR (nucleotides 1-610). S1: nucleotides 1-199, S2: nucleotides 200-400, S3: nucleotides 401-610. The grey box indicates the miR-21 binding site at nucleotides 228-249 [25]. B. UVcrosslinking with GST or GST-HuR and the PDCD4 3'UTR fragments that were in vitro transcribed and ${ }^{32} \mathrm{P}-$ labelled. C. RNA EMSA with increasing concentrations of GST-HuR and in vitro transcribed and ${ }^{32}$ P-labelled PDCD4 S1S2 probe (nucleotides 1-401). The complexes between HuR and PDCD4 S1S2 RNA are indicated as C1, C2, C3, and C4. D. RNA EMSA with 300 nM GST-HuR or GST incubated with $8 \mathrm{nM}$ Cy5.5 3'-end labelled miR-21 RNA and increasing concentrations of $5 \mathrm{pM}, 10 \mathrm{pM}, 15 \mathrm{pM}$, or 20 pM ${ }^{32} \mathrm{P}-\mathrm{UTP}$ labelled, in vitro transcribed S1S2 fragment of PDCD4 RNA. The complexes between HuR and PDCD4 S1S2 RNA are indicated by C1, C2, and C3. The binding between HuR and miR-21 is indicated by HuR:miR-21. Gel was exposed to X-ray film at $-80^{\circ} \mathrm{C}$ to detect autoradiography and subsequently scanned with the Li-Cor Odyssey infrared scanner to detect the miR-21 Cy5.5 signal. 
PDCD4 protein expression after $\mathrm{H}_{2} \mathrm{O}_{2}$ treatment (Figure 4D), suggesting that miR-21 binding is responsible for the reduced PDCD4 expression in response to $\mathrm{H}_{2} \mathrm{O}_{2}$ stress. This result suggests that it is not necessarily the increase in cytoplasmic HuR that is important for PDCD4 regulation, but rather, modifications of the cytoplasmic HuR after $\mathrm{H}_{2} \mathrm{O}_{2}$ treatment that may affect its target binding. We therefore performed the HuR immunoprecipitation after
$\mathrm{H}_{2} \mathrm{O}_{2}$ treatment and observed a loss of PDCD4 binding to HuR after $\mathrm{H}_{2} \mathrm{O}_{2}$ exposure (Figure 4E). These observations point toward a model where under normal growth conditions, a small amount of HuR that is normally found in the cytoplasm binds to the PDCD4 3'UTR and protects it from miR-21 mediated degradation. However, under oxidative stress, HuR is likely modified so that it can no longer bind to PDCD4 mRNA, thus allowing miR-21 to
A

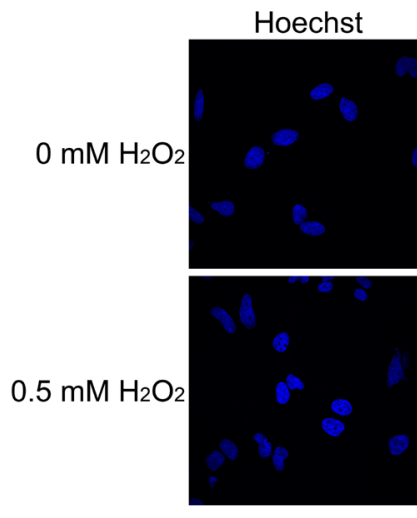

B

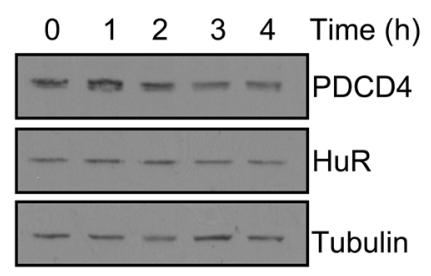

D

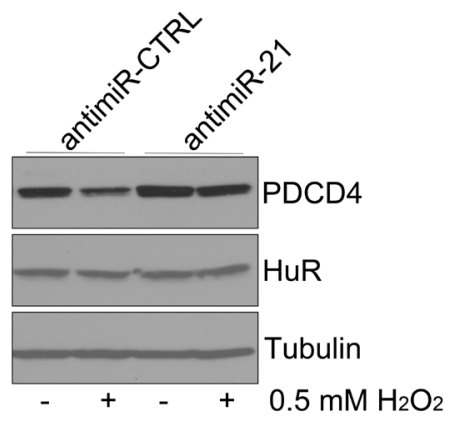

HuR
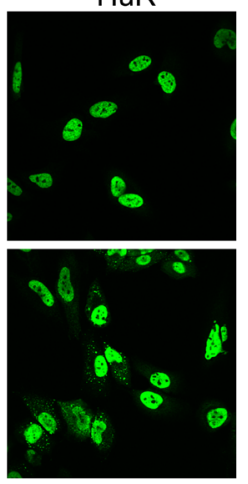

Merge

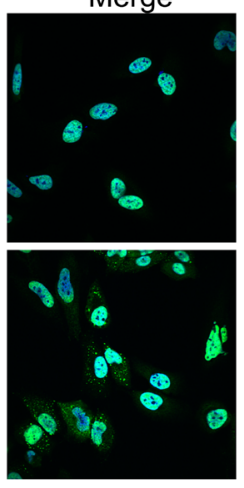

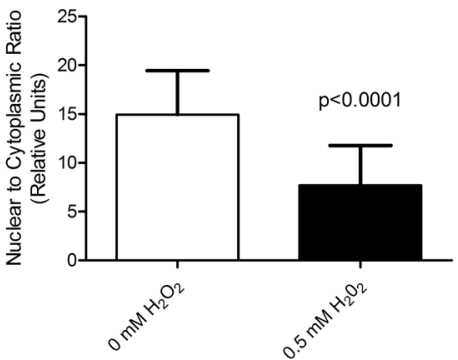

C
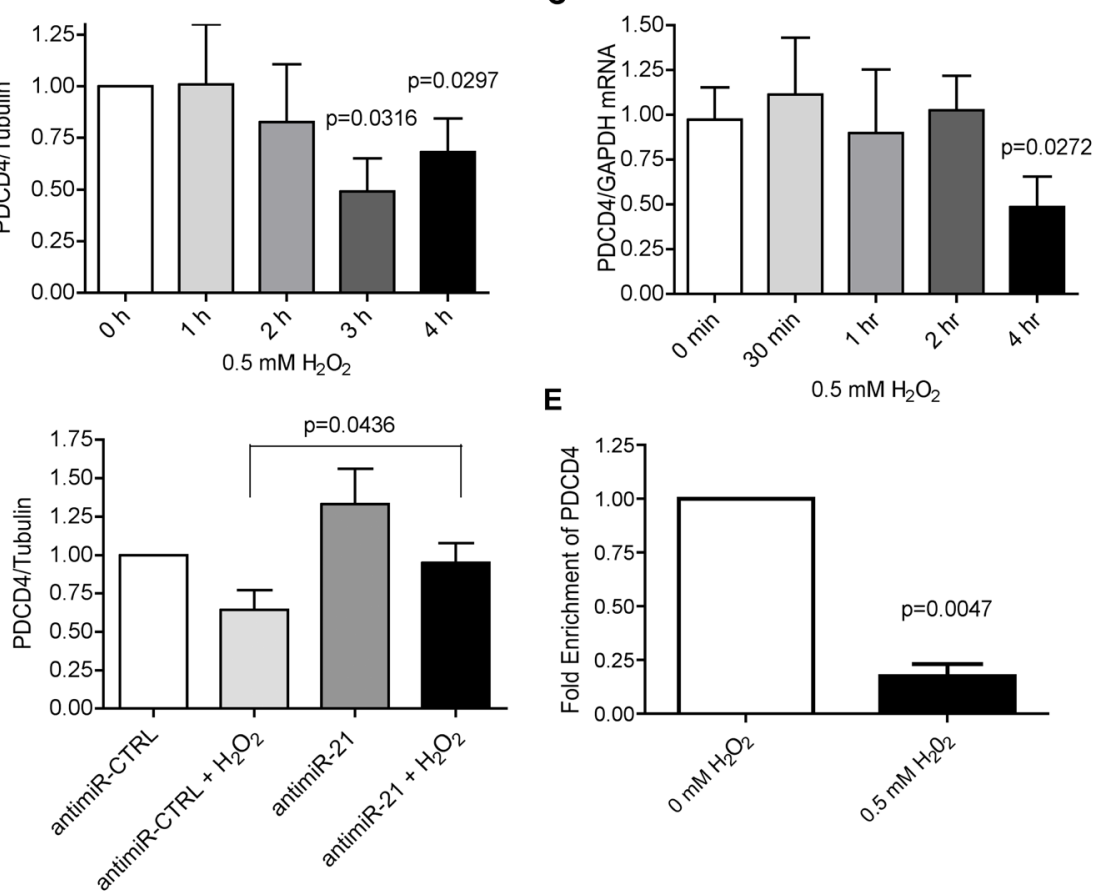

E
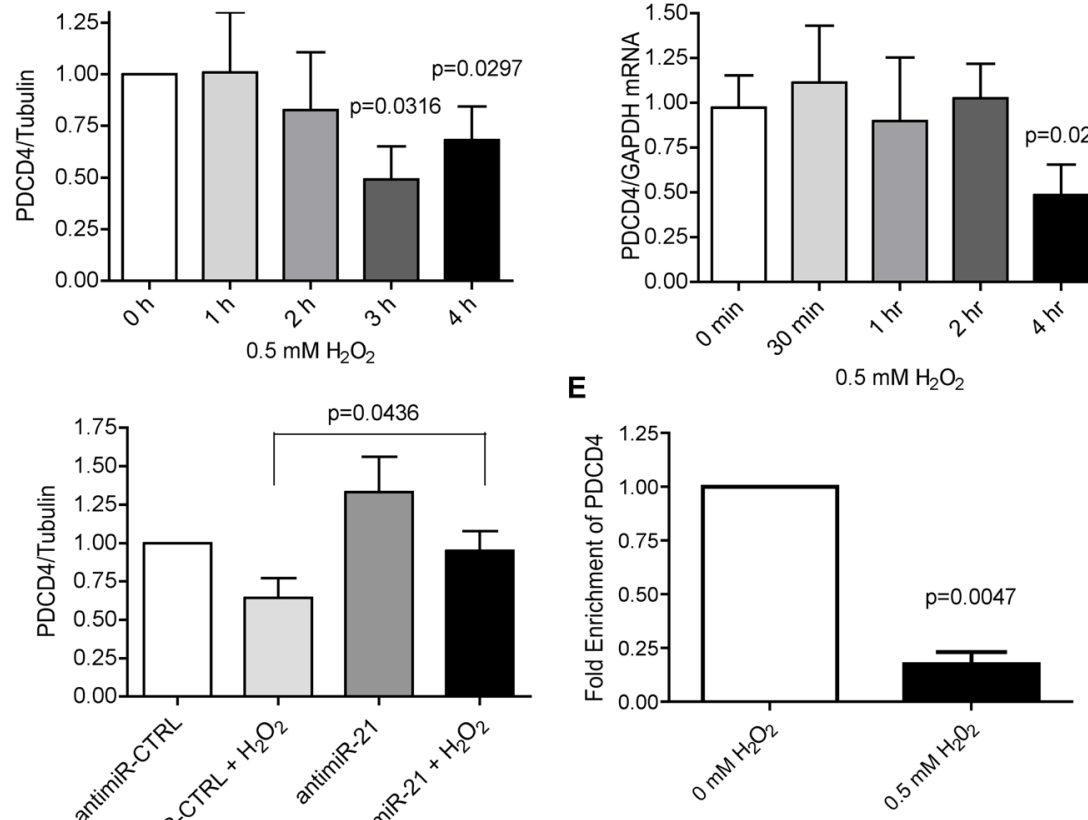

Figure 4: $\mathrm{H}_{2} \mathrm{O}_{2}$ causes cytoplasmic accumulation of $\mathrm{HuR}$ and a loss in PDCD4 expression that is mediated by miR-21. A. HuR localization by immunofluorescence of HeLa cells treated with PBS $\left(0 \mathrm{mM} \mathrm{H}_{2} \mathrm{O}_{2}\right)$ or $0.5 \mathrm{mM} \mathrm{H}_{2} \mathrm{O}_{2}$ for $1 \mathrm{~h}$. Nuclei are visualized by Hoechst staining. Nuclear/Cytoplasmic ratio of HuR is shown on the right. Higher ratio denotes more nuclear staining. B. Left panel: HeLa cells were treated with $0.5 \mathrm{mM} \mathrm{H}_{2} \mathrm{O}_{2}$ for the indicated times and cell lysates analysed by western blot analysis indicating a decrease in PDCD4 protein at $3 \mathrm{~h}$ as compared to Tubulin control. Right panel: PDCD4 protein levels were quantified relative to Tubulin. C. Cells were treated with $0.5 \mathrm{mM} \mathrm{H}_{2} \mathrm{O}_{2}$ for the indicated time points, total RNA was isolated and analysed by qRT-PCR indicating a loss of PDCD4 mRNA as compared to GAPDH control. D. Left panel: HeLa cells were treated with antimiR-21 or a non-targeting antimiR-CTRL (control) for $24 \mathrm{~h}$ followed by treatment with $0.5 \mathrm{mM} \mathrm{H}_{2} \mathrm{O}_{2}$ for $4 \mathrm{~h}$. Cells were harvested and analysed by western blot analysis. Tubulin was used as a loading control. Right panel: Quantification of PDCD4 levels relative to Tubulin. E. HeLa cells were treated with $0.5 \mathrm{mM} \mathrm{H}_{2} \mathrm{O}_{2}$ or PBS and HuR was immunoprecipitated. Bound RNA was isolated and qRT-PCR was performed to determine levels of PDCD4 mRNA. The levels of HuR-bound PDCD4 in PBS-treated cells were set as 1. 
bind to the PDCD4 3'UTR leading to degradation of the mRNA and loss of protein expression.

Previous reports have identified the activation of the kinase ERK8 during $\mathrm{H}_{2} \mathrm{O}_{2}$ stress [30], thus we were interested in determining if $\mathrm{HuR}$ is a potential target of ERK8. We observed that PDCD4 protein levels are rescued after $\mathrm{H}_{2} \mathrm{O}_{2}$ treatment when ERK8 levels are reduced (Figure $5 \mathrm{~B}$ ), even though HuR still accumulates in the cytoplasm (Figure 5A). This data suggests that ERK8 may phosphorylate HuR to change its binding affinity for PDCD4. We therefore performed an in vitro kinase assay to determine if ERK8 can phosphorylate HuR directly. Indeed, we observed that HA-ERK8 specifically phosphorylates $\mathrm{HuR}$, thus identifying $\mathrm{HuR}$ as a novel substrate of the ERK8 signaling pathway (Figure 5C). This data suggests a model where $\mathrm{H}_{2} \mathrm{O}_{2}$ causes activation of ERK8, which subsequently phosphorylates HuR, thus preventing it from binding to the PDCD4 3'UTR and rendering the PDCD4 mRNA accessible to miR-21 and leading to its degradation and loss of protein expression.

A

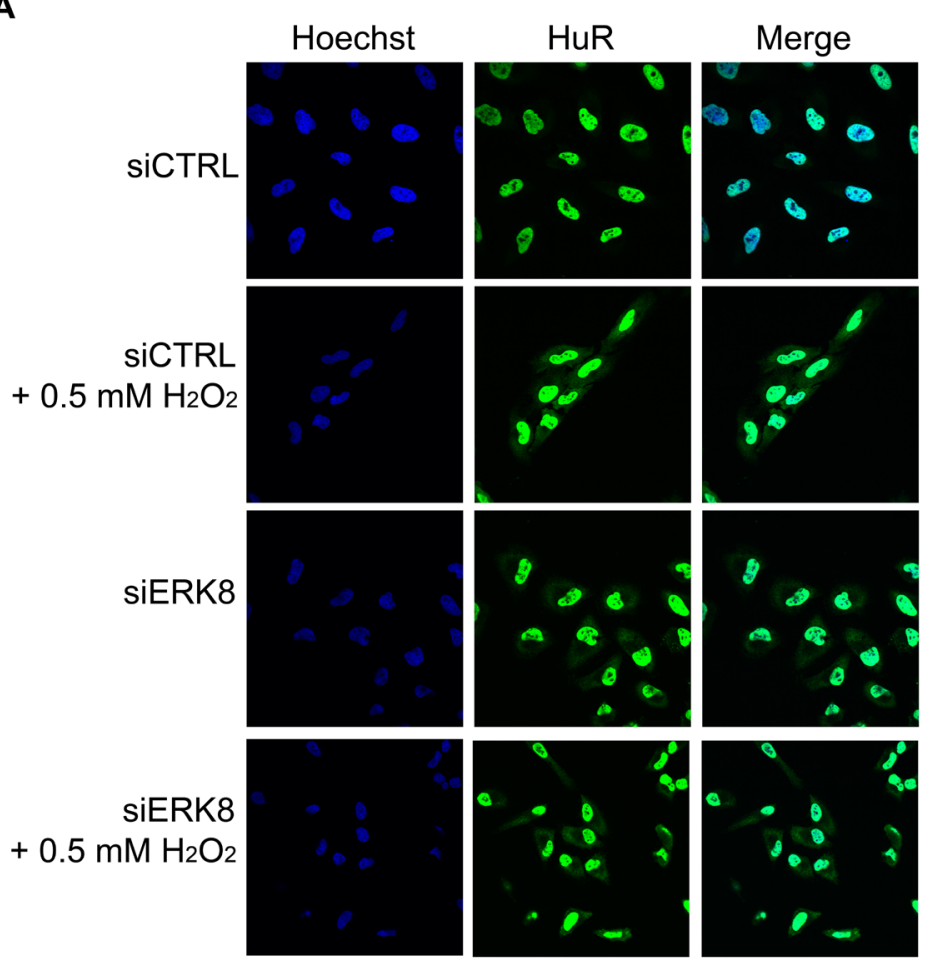

B

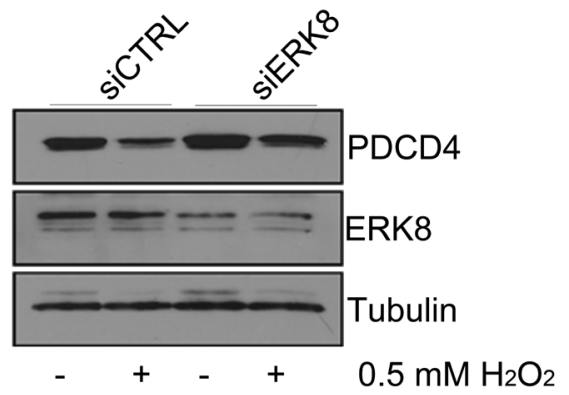

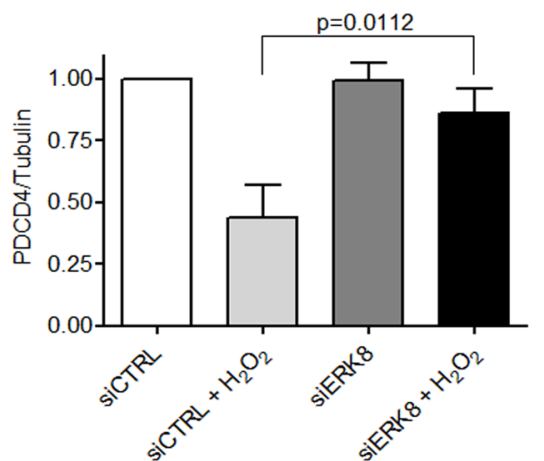

C

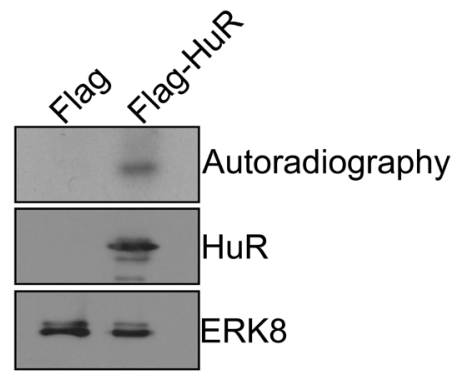

Figure 5: ERK8 phosphorylates HuR to prevent its binding to PDCD4 mRNA. A. ERK8 or control siRNA was transfected into HeLa cells for $48 \mathrm{~h}$ followed by treatment of cells with $0.5 \mathrm{mM} \mathrm{H}_{2} \mathrm{O}_{2}$ or PBS for $1 \mathrm{~h}$. Cells were fixed and immunofluorescence was performed to monitor HuR localization. Hoechst was used to stain the nuclei. Nuclear/Cytoplasmic ratio of HuR is shown on the right. Higher ratio denotes more nuclear staining. B. Top panel: HeLa cells were treated as in (A) and cells were harvested for western blot analysis for indicated proteins. Bottom panel: Quantification of PDCD4 protein levels relative to Tubulin. C. The kinase assay was performed with immunoprecipitated Flag-HuR or Flag empty vector as substrate and HA-ERK8 kinase in the presence of ${ }^{32} \mathrm{P}$ gamma-ATP and exposed to X-ray film. The levels of HuR and ERK8 proteins were detected by western blot analysis. 


\section{DISCUSSION}

Downregulation of the tumour suppressor PDCD4 is correlated with the initiation and progression of lung, colon, liver, breast, and brain cancers [14-18]. Previously, we identified PDCD4 as a regulator of IRES-mediated translation of XIAP and Bcl-xL [22]. This regulation is particularly important in cancer development because loss of PDCD4 correlates with an increase in the expression of these and other apoptosis-regulating proteins, thus contributing to the cell's ability to evade apoptosis following treatment with chemotherapeutics $[18,21]$. The important role of PDCD4 in tumorigenesis highlights a need to elucidate the mechanism of PDCD4 protein regulation. It is known that miR-21 regulates PDCD4 mRNA and targets it for degradation, leading to a loss of protein expression [31]. Moreover, an increase in miR-21 expression has been observed in many cancers, which likely contributes to the frequently observed loss of PDCD4 [25-27]. Since HuR and PDCD4 regulate the same IRES-containing mRNAs [8, 9, 22], and HuR has been implicated in regulating miRNA-mediated degradation of mRNAs, we aimed to determine if $\mathrm{HuR}$ plays a role in regulating PDCD4 expression. Indeed, we observed that HuR regulates PDCD4 protein expression via miR-21. SiRNA-mediated loss of HuR renders PDCD4 mRNA readily available to miR-21 targeting, leading to its degradation and decreased protein levels. Interestingly, both the 3' UTR of PDCD4 and the miR21 target sequence are AU-rich, which is compatible with the HuR RNA target motif [32]. We demonstrate that HuR binds to the PDCD4 3'UTR but that it does not bind to the miR-21 binding site. Instead, our RNA EMSA analysis suggests that initial binding of HuR to the site upstream of the miR-21 binding site causes recruitment and further multimerization of additional HuR proteins that sterically hinder miR-21 binding. Furthermore, EMSA analysis suggests that HuR can bind both miR21 and PDCD4 mRNA. However, HuR has a higher affinity for the PDCD4 mRNA, which results in the observed effect on PDCD4 mRNA stability and protein expression.

After cellular stress, HuR exits the nucleus and accumulates in the cytoplasm where it typically binds to and stabilizes target mRNAs. Therefore, we were expecting to see a rescue in PDCD4 expression after exposing cells to $\mathrm{H}_{2} \mathrm{O}_{2}$ stress. Unexpectedly, although we observed a cytoplasmic accumulation of $\mathrm{HuR}$ following $\mathrm{H}_{2} \mathrm{O}_{2}$ treatment, we did not observe a rescue of PDCD4 expression. Instead, $\mathrm{H}_{2} \mathrm{O}_{2}$ treatment led to the loss in both PDCD4 protein and mRNA levels. This observation suggests that it is not the accumulation of $\mathrm{HuR}$ in the cytoplasm that is affecting PDCD4 levels, but rather, the modification of the already cytoplasmic $\mathrm{HuR}$ after $\mathrm{H}_{2} \mathrm{O}_{2}$ treatment that is causing the effect. It is possible that $\mathrm{HuR}$ is phosphorylated following $\mathrm{H}_{2} \mathrm{O}_{2}$, which prevents it from being able to bind to its target
mRNA. A similar observation had been previously described by Abdelmohsen and colleagues [33], where they demonstrated that $\mathrm{H}_{2} \mathrm{O}_{2}$ causes phosphorylation of HuR by Chk2 thus leading to dissociation of HuR from SIRT1 mRNA and a consequent loss in SIRT1 protein. Additionally, Yoon and colleagues [34] demonstrated that tyrosine phosphorylation of HuR by JAK3 following arsenite treatment caused a dissociation of HuR from SIRT1 and VHL target mRNAs leading to their degradation. These findings point to a role for posttranslational modifications of HuR in determining HuR's ability to bind target mRNAs. Since knockdown of Chk2 followed by $\mathrm{H}_{2} \mathrm{O}_{2}$ treatment had no effect of PDCD4 levels (data not shown) we sought to determine which kinase is regulating HuR's effect on PDCD4. Recently, ERK8 was shown to be activated in response to $\mathrm{H}_{2} \mathrm{O}_{2}$ stress [30]. Therefore, we monitored the effect of ERK8 silencing on PDCD4 levels. We determined that loss of ERK8 rescues the levels of PDCD4 protein after $\mathrm{H}_{2} \mathrm{O}_{2}$ treatment and that ERK8 specifically and directly phosphorylates HuR in vitro, thus identifying HuR as a novel target of ERK8 kinase activity.

Interestingly, although there is increased expression of both cytoplasmic HuR and miR-21 in primary Glioblastoma cells [27, 35-37], the expression of PDCD4 in these cells is reduced. While the ratio of cytoplasmic HuR and miR-21 will determine the fate of PDCD4 mRNA, we have shown that the binding affinity of HuR is also critical for PDCD4 regulation. Therefore, in addition to monitoring levels of HuR and miR-21, one should consider assessing the activity of ERK 8 and/or other kinases that may phosphorylate HuR to alter its binding affinity for specific targets.

\section{MATERIALS AND METHODS}

\section{Cell culture, expression constructs, and transfection}

HeLa cells were maintained in standard conditions in Dulbecco's modified Eagle's medium (DMEM) supplemented with heat-inactivated $10 \%$ fetal calf serum, $2 \mathrm{mM}$ L-glutamine, and $1 \%$ antibiotics (100 units $/ \mathrm{ml}$ penicillin-streptomycin). The GST-HuR expression plasmid was described previously [38]. Transfections of siRNA, or miRVana microRNA mimics and inhibitors were performed using Lipofectamine RNAiMax (Life Technologies). Briefly, $2.5 \times 10^{4} \mathrm{HeLa}$ cells were seeded in 12-well plates for 24 hours. Transfections were performed at a final concentration of $20 \mathrm{nM} \mathrm{HuR}$ siRNA (AAGUCUGUUCAGCAGCAUUGGUUdTdT, Dharmacon), nonsilencing control (Qiagen, Cat. \# 1022076), miR-21 mimic (Ambion, Cat. \# 4464066), miR negative Control mimic (Ambion, Cat. \# 4464058), 
anti-miR-21 (Ambion, Cat. \# 4464084), anti-miR control (Ambion, Cat. \# 4464076). Cells were treated in the presence of $0.5 \mathrm{mM} \mathrm{H}_{2} \mathrm{O}_{2}$ for 4 hours. Cells were harvested for analysis after the indicated time points as described below.

\section{Western blot analysis}

Cells were washed with PBS, scraped, and transferred to an Eppendorf tube. Cells were pelleted and resuspended in RIPA buffer (50 mM Tris- $\mathrm{HCl}[\mathrm{pH}$ 7.4], $1 \mathrm{mM}$ EDTA, $150 \mathrm{mM} \mathrm{NaCl}, 1 \% \mathrm{NP}-40,0.5 \%$ SDS, $1 \mathrm{mM}$ PMSF) for 15 minutes on ice. Lysates were centrifuged at $12,000 \times \mathrm{g}$ for 15 minutes to pellet cell debris. Bradford Assay (Bio-Rad) was used to quantify protein concentration and equal concentrations were loaded on $10 \%$ SDS-PAGE gels. Proteins were transferred to a PVDF membrane and analysed by rabbit anti-PDCD4 (Rockland, CAT\# 600-401-965), mouse anti-HuR (Santa Cruz Biotechnology, CAT\# sc-5261), mouse anti-Tubulin (Abcam, CAT\# ab7291), rabbit anti-GST (Santa Cruz Biotechnology, sc-459), and goat anti-ERK8 (Santa Cruz Biotechnology, CAT\# sc-86723) antibodies followed by species-specific HRP-conjugated secondary antibodies (Cell Signaling Technology). Antibody complexes were detected using an ECL or ECL Plus system (GE Biosciences) and were quantified using Odyssey densitometry software (Li-COR Biosciences).

\section{RNA extraction and quantitative RT-PCR (qRT- PCR) analysis}

Total RNA was isolated from cells using RNAzol (Molecular Research Center, Inc.) as per manufacturer's protocol. cDNA was generated using the First-strand cDNA synthesis kit (GE Biosciences). Quantitative PCR was performed using the QuantiTect SYBR green PCR kit (Qiagen) with gene specific primers for PDCD4 (QuantiTect Primer Assay; Qiagen) and GAPDH [22].

\section{Actinomycin D}

Seventy-two hours after siRNA transfection, HeLa cells were treated with actinomycin D (Sigma-Aldrich), dissolved in anhydrous ethanol, at a final concentration of $5 \mu \mathrm{g} / \mathrm{mL}$. After the chase period, cells were processed for qRT-PCR to determine their half-life $\left(t_{1 / 2}\right)$ as described [39]

\section{In vitro synthesis of ${ }^{32} \mathrm{P}$-labelled RNA and UV- crosslinking}

The first 610 nt of the PDCD4 3'UTR containing the miR-21 binding site (228-249 nt; [25]) was cloned after the chloramphenicol acetyl transferase (CAT) coding sequence in the pMC.pa plasmid described in [39] using the forward (5'-CAGGATCCATATAAGAACTCTTGCAGTC) and the reverse (5'-CTTCTAGAACCAGGTTCATTTTTCC) primers. DNA templates containing the $\mathrm{T} 7$ promoter were generated from this pMC.PDCD4 3'UTR. pa plasmid by PCR (S1 fragment: forward primer 5'-CAGGATCCATATAAGAACTCTTGCAGTC, reverse primer 5'- CTTCTAGACTTGCCCCCTCGAAAAAC; S2 fragment: forward primer 5'CAGGATCCGAGGGACAGAAAAGTAAC, reverse primer 5'- CTTCTAGATTTTAGCAGCTTAACTTT; S3 fragment: forward primer 5'-CAGGATCCCCCCATGTTGGCTGCTGC, reverse primer 5'- GGAAAAATGAACCTGGTTCTAGAAG). RNA was generated using $\left[\alpha-{ }^{32} \mathrm{P}\right]$ UTP and a MAXIscript T7 kit (Ambion) as per the manufacturer's protocol. The RNA was run on a $5 \%$ acrylamide- $8 \mathrm{M}$ urea denaturing gel, excised and eluted in RNase free water overnight at $37^{\circ} \mathrm{C}$. The RNA was then incubated with purified GST or GST-HuR in RNA binding buffer (10 mM Tris-HCl [pH 7.4], $3 \mathrm{mM} \mathrm{MgCl}, 300 \mathrm{mM} \mathrm{KCl}, 1 \mathrm{mM}$ dithiothreitol [DTT], $0.2 \mathrm{mM}$ PMSF, leupeptin [20 $\mu \mathrm{g} / \mathrm{ml}$ ]) for 30 minutes at room temperature then cross-linked at $250 \mathrm{~mJ} /$ $\mu \mathrm{m}^{2}$ in a Stratalinker. The complexes were treated with RNase T1 (1 U/ $\mu \mathrm{l})$, RNase A $(10 \mu \mathrm{g} / \mathrm{ml})$, and heparin $(5 \mathrm{mg} / \mathrm{ml})$ for 10 minutes. The samples were separated by SDS-PAGE gel, and exposed to X-ray film at $-80^{\circ} \mathrm{C}$ overnight.

\section{GST-tag protein purification}

E. coli was transformed with the pGEX or pGEXKG_HuR plasmid and grown overnight in $4 \mathrm{~mL}$ LuriaBertani (LB) media containing ampicillin $(100 \mathrm{mg} / \mathrm{mL})$. The culture was added to $100 \mathrm{~mL}$ of LB media containing $100 \mathrm{mg} / \mathrm{mL}$ of ampicillin and grown to an OD of 0.7 . Isopropylthio- $\beta$-galactoside (IPTG) was added to a final concentration of $1 \mathrm{mM}$ and grown for 4 hours longer. The cultures were centrifuged at $5000 \mathrm{x}$ g for 10 minutes at $4{ }^{\circ} \mathrm{C}$ and supernatant discarded. The pellet was resuspended in $10 \mathrm{~mL}$ of ice-cold PBS and the samples were centrifuged again at $5000 \mathrm{x}$ g for 10 minutes at $4^{\circ} \mathrm{C}$. Samples were then lysed with $10 \mathrm{~mL}$ lysis buffer $(50 \mathrm{mM}$ Tris- $\mathrm{HCl}[\mathrm{pH}$ 8.0], $200 \mathrm{mM} \mathrm{NaCl}, 1 \mathrm{mM}$ EDTA, $1 \mathrm{mM}$ DTT, $2 \mathrm{mM}$ PMSF). Lysates were sonicated twice, 1\% Triton X-100 was added, and samples were sonicated again. Samples were centrifuged at $13000 \mathrm{x}$ g for 10 minutes at $4^{\circ} \mathrm{C}$. Glutathione sepharose beads (200 $\mu \mathrm{L}$; GE Healthcare) were added to the supernatant and rotated at $4{ }^{\circ} \mathrm{C}$ for 2 hours. Samples were washed 5 times with cold PBS and proteins were eluted using $20 \mathrm{mM}$ L-glutathione, $\mathrm{pH} 8.0$ in PBS rotating at $4^{\circ} \mathrm{C}$ for 1 hour. 


\section{RNA-protein complex immunoprecipitation}

HeLa cells were treated with $0.5 \mathrm{mM} \mathrm{H}_{2} \mathrm{O}_{2}$ for 4 hours, washed twice with PBS and lysed in CHIP lysis buffer (50 mM Hepes-KOH pH 7.5, $140 \mathrm{mM} \mathrm{NaCl}, 1 \mathrm{mM}$ EDTA pH 8.0, 1\% Triton X-100, 0.1\% SDS, 0.1\% sodium deoxycholate, $1 \mathrm{mM}$ PMSF, $5 \mu \mathrm{g} / \mathrm{mL}$ Aprotinin, $10 \mu \mathrm{g} / \mathrm{mL}$ Leupeptin, $40 \mathrm{U} / \mathrm{mL}$ RNase inhibitor) for 30 minutes on ice. Lysates were spun at 13, $000 \mathrm{rpm}$ for 15 minutes and supernatant was transferred to a new tube. Samples were incubated with $10 \mu \mathrm{g}$ mouse anti-HuR or anti-mouse IgG for 2 hours at $4^{\circ} \mathrm{C}$. Dynabeads Protein $\mathrm{G}$ (Novex by Life Technologies) were washed with CHIP buffer and added to samples ( $50 \mu \mathrm{L}$ per sample) and rotated for 40 minutes at $4^{\circ} \mathrm{C}$. Supernatant was removed and beads were washed 4 times with CHIP buffer. RNA was extracted with RNAzol as per manufacturer's protocol and qPCR was performed using the QuantiTect SYBR green PCR kit (Qiagen).

\section{Immunofluorescence}

Cells were grown on coverslips and treated with $\mathrm{H}_{2} \mathrm{O}_{2}$ or PBS as indicated and fixed with $3 \%$ formaldehyde in PBS for 10 minutes at room temperature. Cells were permeablized with $0.1 \%$ Triton X-100 in PBS for 5 minutes at room temperature on a shaker, rinsed twice with PBS, and blocked with 5\% bovine serum albumin (BSA) in PBS for 1 hour. Primary antibody was added (mouse anti-HuR (1:500 dilution in 5\% BSA in PBS) and incubated with cells overnight at $4{ }^{\circ} \mathrm{C}$, followed by 3 washes with PBS for 5 minutes each. Secondary antibody (alexa fluor 488 goat anti-mouse (Life Technologies; 1:1000 dilution in PBS) was added for 1 hour followed by three 5 minute washes in PBS. Nuclei were stained with Hoechst 33342 (Pierce) for 5 minutes and washed with PBS twice. Coverslips were mounted on slides using Fluoromount (Sigma Aldrich). Confocal microscopy was performed using the $60 \mathrm{X}$ objective with immersion oil (Olympus Fluoview FV1000, Richmond Hill, Ontario Canada). Quantification of HuR nuclear and cytoplasmic distribution was done as described previously [40] with some modifications. The images were analyzed on a Columbus Image Analysis Server (Perkin Elmer) using an embedded Acapella Image Analysis Software (Perkin Elmer) script. Nuclei were segmented and defined using their Hoechst 33342 staining. The cytoplasmic region was defined as a ring of 9 pixel width that encircled the nucleus 1 pixels away from its outside edge. The nuclear/ cytoplasmic ratio of HuR was calculated from the average intensity of HuR fluorescent signal measured per cell within these regions. Higher ratio number represent more nuclear distribution.

\section{RNA electromobility shift assay}

Recombinant GST or GST-HuR was incubated with ${ }^{32} \mathrm{P}$-labelled, in vitro transcribed RNA probe in RNA binding buffer (10 mM Tris-HCl PH 7.5, $1.5 \mathrm{mM}$ $\mathrm{MgCl}_{2}, 50 \mathrm{mM} \mathrm{KCl}, 0.5 \mathrm{mM}$ DTT) for 30 minutes at room temperature with or without Cy5.5 3'-labelled miR21 RNA (Dharmacon). The complexes were separated on a $6 \%$ polyacrylamide gel and the gel was exposed to X-ray film at $-80^{\circ} \mathrm{C}$ to detect autoradiography and subsequently scanned with the Li-Cor Odyssey infrared scanner (LiCor Biosciences, Lincoln, NE) to detect the miR21 Cy5.5 signal.

\section{Kinase assay}

pCDNA3_Flag-HuR, pReciever_HA-ERK8, or pCDNA3_Flag empty vector were transfected into HeLa cells for $24 \mathrm{~h}$ and harvested in co-immunoprecipitation buffer $(25 \mathrm{mM}$ Tris [pH 7.5], $150 \mathrm{mM} \mathrm{NaCl}, 50 \mathrm{mM}$ NaF, 0.5 mM EDTA [pH 8.0], 0.5\% Triton X-100, 5 $\mathrm{mM}$ beta glycerophosphate, $5 \%$ glycerol, $1 \mathrm{mM}$ DTT, 1 mM PMSF, $1 \mathrm{mM} \mathrm{Na}_{3} \mathrm{VO}_{4}$ ). Lysates were sonicated and centrifuged for $15 \mathrm{~min}$ at $13,000 \mathrm{x}$ g at $4^{\circ} \mathrm{C}$. Anti-Flag agarose beads (Sigma) were incubated with the lysate for $1 \mathrm{~h}$ at $4^{\circ} \mathrm{C}$ and washed 3 times in lysis buffer followed by a wash in kinase buffer (20 mM Tris- $\mathrm{HCl}$ [pH 7.5], $5 \mathrm{mM}$ beta-glycerolphosphate, $0.2 \mathrm{mM} \mathrm{Na}_{3} \mathrm{VO}_{4}, 0.5 \mathrm{mM}$ DTT). Kinase and substrate on beads were incubated in kinase buffer in the presence of ( $30 \mu \mathrm{M}$ ATP, $6.6 \mathrm{mM} \mathrm{MgCl} 2,3.3$ $\mathrm{mM} \mathrm{MnCl}$ ) and $5 \mu \mathrm{Ci}$ of $\gamma-{ }^{32} \mathrm{P}$-labelled ATP for $20 \mathrm{~min}$ at $30^{\circ} \mathrm{C}$. Laemmli sample buffer was added, and samples were separated by SDS-PAGE, transferred to a PVDF membrane, and exposed to X-ray film. The membrane was subsequently analyzed by Western blotting.

\section{Statistical analysis}

An unpaired t-test was performed using GraphPad Prism version 5.00 for Windows (GraphPad Software, San Diego, CA) to determine p-value in repeated experiments. All results are shown as mean \pm standard deviation. For RT-qPCR experiments, average RNA expression was calculated using data collected from three biological replicates and three technical replicates for each biological replicate. Unless otherwise noted, all results were obtained through a minimum of three independent experimental replications.

\section{ACKNOWLEDGMENTS}

We are indebted to our colleagues for fruitful and frequently spirited discussions. This work forms part of the Ph.D. dissertation of ULM. 


\section{FUNDING}

This work was supported by operating grants from the Natural Sciences and Engineering Research Council of Canada [RGPIN 250100-2010]; the Canadian Institutes of Health Research [MOP 89737, FRN 74740]; and Cancer Research Society (CRS) to MH. ULM was supported by the Ontario Graduate Scholarship. The authors have no competing financial interests in relation to the work described in this manuscript.

\section{CONFLICTS OF INTEREST}

There is no conflict of interest.

\section{REFERENCES}

1. Ma WJ, Cheng S, Campbell C, Wright A and Furneaux H. Cloning and characterization of HuR, a ubiquitously expressed Elav-like protein. J Biol Chem. 1996; 271:81448151.

2. Izquierdo $\mathrm{JM}$. $\mathrm{Hu}$ antigen $\mathrm{R}(\mathrm{HuR})$ functions as an alternative pre-mRNA splicing regulator of Fas apoptosispromoting receptor on exon definition. J Biol Chem. 2008; 283:19077-19084.

3. Yi J, Chang N, Liu X, Guo G, Xue L, Tong T, Gorospe M and Wang W. Reduced nuclear export of HuR mRNA by $\mathrm{HuR}$ is linked to the loss of HuR in replicative senescence. Nucleic Acids Res. 2010; 38:1547-1558.

4. Dai $\mathrm{W}$, Zhang $\mathrm{G}$ and Makeyev EV. RNA-binding protein HuR autoregulates its expression by promoting alternative polyadenylation site usage. Nucleic Acids Res. 2012; 40:787-800.

5. Wang W, Furneaux H, Cheng H, Caldwell MC, Hutter D, Liu Y, Holbrook N and Gorospe M. HuR regulates p21 mRNA stabilization by UV light. Mol Cell Biol. 2000; 20:760-769.

6. Kuwano Y, Kim HH, Abdelmohsen K, Pullmann R, Jr., Martindale JL, Yang X and Gorospe M. MKP-1 mRNA stabilization and translational control by RNA-binding proteins HuR and NF90. Mol Cell Biol. 2008; 28:45624575.

7. Prechtel AT, Chemnitz J, Schirmer S, Ehlers C, LangbeinDetsch I, Stulke J, Dabauvalle MC, Kehlenbach RH and Hauber J. Expression of CD83 is regulated by HuR via a novel cis-active coding region RNA element. J Biol Chem. 2006; 281:10912-10925.

8. Durie D, Lewis SM, Liwak U, Kisilewicz M, Gorospe $\mathrm{M}$ and Holcik M. RNA-binding protein HuR mediates cytoprotection through stimulation of XIAP translation. Oncogene. 2011; 30:1460-1469.

9. Durie D, Hatzoglou M, Chakraborty P and Holcik M. HuR controls mitochondrial morphology through the regulation of BclxL translation. Translation. 2013; 1(1).
10. Meng Z, King PH, Nabors LB, Jackson NL, Chen CY, Emanuel PD and Blume SW. The ELAV RNA-stability factor HuR binds the 5'-untranslated region of the human IGF-IR transcript and differentially represses cap-dependent and IRES-mediated translation. Nucleic Acids Res. 2005; 33:2962-2979. Print 2005.

11. Srikantan S, Tominaga K and Gorospe M. Functional interplay between RNA-binding protein $\mathrm{HuR}$ and microRNAs. Curr Protein Pept Sci. 2012; 13:372-379.

12. Wang J, Guo Y, Chu H, Guan Y, Bi J and Wang B. Multiple Functions of the RNA-Binding Protein HuR in Cancer Progression, Treatment Responses and Prognosis. Int J Mol Sci. 2013; 14:10015-10041.

13. Shibahara K, Asano M, Ishida $Y$, Aoki T, Koike T and Honjo T. Isolation of a novel mouse gene MA-3 that is induced upon programmed cell death. Gene. 1995; 166:297301.

14. Chen Y, Knosel T, Kristiansen G, Pietas A, Garber ME, Matsuhashi S, Ozaki I and Petersen I. Loss of PDCD4 expression in human lung cancer correlates with tumour progression and prognosis. J Pathol. 2003; 200(5):640-646.

15. Afonja O, Juste D, Das S, Matsuhashi S and Samuels HH. Induction of PDCD4 tumor suppressor gene expression by RAR agonists, antiestrogen and HER-2/neu antagonist in breast cancer cells. Evidence for a role in apoptosis. Oncogene. 2004; 23:8135-8145.

16. Zhang H, Ozaki I, Mizuta T, Hamajima H, Yasutake T, Eguchi Y, Ideguchi H, Yamamoto K and Matsuhashi S. Involvement of programmed cell death 4 in transforming growth factor-beta1-induced apoptosis in human hepatocellular carcinoma. Oncogene. 2006; 25:6101-6112.

17. Mudduluru G, Medved F, Grobholz R, Jost C, Gruber A, Leupold JH, Post S, Jansen A, Colburn NH and Allgayer H. Loss of programmed cell death 4 expression marks adenoma-carcinoma transition, correlates inversely with phosphorylated protein kinase $\mathrm{B}$, and is an independent prognostic factor in resected colorectal cancer. Cancer. 2007; 110:1697-1707.

18. Liwak U, Jordan LE, Von-Holt SD, Singh P, Hanson JE, Lorimer IA, Roncaroli F and Holcik M. Loss of PDCD4 contributes to enhanced chemoresistance in Glioblastoma multiforme through de-repression of Bcl-xL translation. Oncotarget. 2013; 4:1365-1372. doi: 10.18632/ oncotarget.1154.

19. Yang HS, Jansen AP, Komar AA, Zheng X, Merrick WC, Costes S, Lockett SJ, Sonenberg N and Colburn NH. The transformation suppressor Pdcd4 is a novel eukaryotic translation initiation factor $4 \mathrm{~A}$ binding protein that inhibits translation. Mol Cell Biol. 2003; 23:26-37.

20. Suzuki C, Garces RG, Edmonds KA, Hiller S, Hyberts SG, Marintchev A and Wagner G. PDCD4 inhibits translation initiation by binding to eIF4A using both its MA3 domains. Proc Natl Acad Sci U S A. 2008; 105:3274-3279.

21. Wedeken L, Singh P and Klempnauer KH. Tumor 
suppressor protein Pdcd4 inhibits translation of p53 mRNA. J Biol Chem. 2011; 286:42855-42862.

22. Liwak U, Thakor N, Jordan LE, Roy R, Lewis SM, Pardo OE, Seckl M and Holcik M. Tumor suppressor PDCD4 represses internal ribosome entry site-mediated translation of antiapoptotic proteins and is regulated by S6 kinase 2 . Mol Cell Biol. 2012; 32:1818-1829.

23. Dorrello NV, Peschiaroli A, Guardavaccaro D, Colburn NH, Sherman NE and Pagano M. S6K1- and betaTRCPmediated degradation of PDCD4 promotes protein translation and cell growth. Science. 2006; 314:467-471.

24. Pardo OE, Wellbrock C, Khanzada UK, Aubert M, Arozarena I, Davidson S, Bowen F, Parker PJ, Filonenko VV, Gout IT, Sebire N, Marais R, Downward J and Seckl MJ. FGF-2 protects small cell lung cancer cells from apoptosis through a complex involving PKCepsilon, B-Raf and S6K2. Embo J. 2006; 25:3078-3088.

25. Asangani IA, Rasheed SA, Nikolova DA, Leupold JH, Colburn NH, Post S and Allgayer H. MicroRNA-21 (miR21) post-transcriptionally downregulates tumor suppressor Pdcd4 and stimulates invasion, intravasation and metastasis in colorectal cancer. Oncogene. 2008; 27:2128-2136.

26. Frankel LB, Christoffersen NR, Jacobsen A, Lindow M, Krogh A and Lund AH. Programmed cell death 4 (PDCD4) is an important functional target of the microRNA miR-21 in breast cancer cells. J Biol Chem. 2008; 283:1026-1033.

27. Gaur AB, Holbeck SL, Colburn NH and Israel MA. Downregulation of Pdcd4 by mir-21 facilitates glioblastoma proliferation in vivo. Neuro Oncol. 2011; 13:580-590.

28. Kundu P, Fabian MR, Sonenberg N, Bhattacharyya SN and Filipowicz W. HuR protein attenuates miRNA-mediated repression by promoting miRISC dissociation from the target RNA. Nucleic Acids Res. 2012; 40:5088-5100.

29. Lin Y, Liu X, Cheng Y, Yang J, Huo Y and Zhang C. Involvement of MicroRNAs in hydrogen peroxide-mediated gene regulation and cellular injury response in vascular smooth muscle cells. J Biol Chem. 2009; 284:7903-7913. doi: 7910.1074/jbc.M806920200.

30. Klevernic IV, Stafford MJ, Morrice N, Peggie M, Morton S and Cohen P. Characterization of the reversible phosphorylation and activation of ERK8. Biochem J. 2006; 394:365-373.

31. Asangani IA, Rasheed SA, Nikolova DA, Leupold JH, Colburn NH, Post S and Allgayer H. MicroRNA-21 (miR21) post-transcriptionally downregulates tumor suppressor Pdcd4 and stimulates invasion, intravasation and metastasis in colorectal cancer. Oncogene. 2008; 27:2128-2136.

32. Lopez de Silanes I, Zhan M, Lal A, Yang X and Gorospe M. Identification of a target RNA motif for RNA-binding protein HuR. Proc Natl Acad Sci U S A. 2004; 101:29872992.

33. Abdelmohsen $\mathrm{K}$ and Gorospe M. Posttranscriptional regulation of cancer traits by HuR. Wiley Interdiscip Rev RNA. 2010; 1:214-229.
34. Yoon JH, Abdelmohsen K, Srikantan S, Guo R, Yang X, Martindale JL and Gorospe M. Tyrosine phosphorylation of HuR by JAK 3 triggers dissociation and degradation of HuR target mRNAs. Nucleic Acids Res. 2014; 42:1196-1208.

35. Bolognani F, Gallani AI, Sokol L, Baskin DS and MeisnerKober N. mRNA stability alterations mediated by HuR are necessary to sustain the fast growth of glioma cells. J Neurooncol. 2012; 106:531-542.

36. Filippova N, Yang X, Wang Y, Gillespie GY, Langford C, King PH, Wheeler $\mathrm{C}$ and Nabors LB. The RNA-binding protein $\mathrm{HuR}$ promotes glioma growth and treatment resistance. Mol Cancer Res. 2011; 9:648-659.

37. Gabriely G, Wurdinger T, Kesari S, Esau CC, Burchard J, Linsley PS and Krichevsky AM. MicroRNA 21 promotes glioma invasion by targeting matrix metalloproteinase regulators. Mol Cell Biol. 2008; 28:5369-5380.

38. Mazroui R, Di Marco S, Clair E, von Roretz C, Tenenbaum SA, Keene JD, Saleh M and Gallouzi IE. Caspase-mediated cleavage of HuR in the cytoplasm contributes to pp32/ PHAP-I regulation of apoptosis. J Cell Biol. 2008; 180:113127.

39. Zhao TT, Graber TE, Jordan LE, Cloutier M, Lewis SM, Goulet I, Cote J and Holcik M. hnRNP A1 regulates UVinduced NF-kappaB signalling through destabilization of cIAP1 mRNA. Cell Death Differ. 2009; 16:244-252.

40. Courteau L, Crasto J, Hassanzadeh G, Baird SD, Hodgins J, Liwak-Muir U, Fung G, Luo H, Stojdl DF, Screaton RA and Holcik M. Hexokinase 2 controls cellular stress response through localization of an RNA-binding protein. Cell Death Dis. 2015; 6:e1837.(doi):10.1038/cddis.2015.1209. 